\title{
Education for Future Librarians
}

Dr. Carman is dean of Columbia College, Columbia University.

$A^{s}$ citizens and members of a profesA sion, librarians are not different from other people in other walks of life. Their need for general education is as great as for journalists, physicians, engineers, or lawyers. All should have opportunity for a broad educational foundation upon which to build their specialty.

Any vocation or profession pursued without knowledge of its total social meaning is apt to be boring and stultifying. In the past too many of our professional and vocational schools unfortunately have insisted that the student ignore so-called cultural subjects and concern himself with courses narrowly professional or vocational. The results have been inevitable. Our colleges and universities have graduated men and women technically trained as librarians, physicians, lawyers or social workers with little or no interest in the cultural implications of their professions, much less in those things which enable them to formulate for themselves a satisfying philosophy of life. Vocationally, professionally, and technologically we are the wonder of the world, but in the realm where circumstances demand virtue and political fitness -an acquaintance with the past, high character, broad sympathies, objectivity, a sense of responsibility, a disinterested understanding of the springs of human actionwe have been much less successful. The

1 Abstract of address presented at the Conference of Eastern College Librarians, Columbia University, Nov. $27, \quad 1948$. social, political and esthetic incapacity of the person without general education and, therefore, without cultural background and trained only in the techniques of his work, is likely to be appalling.

Ours is a democratic society, and from the days when the first white settler put foot on this continent to the present the concepts of human freedom and human betterment and happiness have been the main roots of American democracy, though at times partially choked by the weeds of selfishness, corruption and crass materialism.

If freedom is the cornerstone of the American way of life, what does it imply? What are its implications for those who enjoy freedom and those who seek it at a time when freedom and free institutions are challenged by regimented statism?

Freedom in a democracy does not mean absolute freedom but freedom to think, believe, disbelieve, speak, and choose. People are free when they are masters of themselves. We become masters of ourselves, as Dr. Henderson of the New York State Department of Education has so well said, when we have learned to utilize fully and creatively our individual abilities-intellectual, physical, emotional. People are not free who are handicapped with unnecessary psychological inhibitions, who are victims of preventable disease, who harbor irrational prejudices against men of differing views, cultures or races, or who practice religious bigotry.

The dangers to the American way of life are not all without; rather the most danger- 
ous are within. They are suspicion, prejudice, intolerance, hate, bigotry, and the worship of mammon. No institution, whether it be a business, home, church, school, or even democracy itself, can long endure the weakening processes of these poisonous enemies. People are free in the degree to which they possess the tools of learning and techniques of action, the ability to verbalize, analyze, synthesize, create, organize, and administer, and who, deep in their souls, have the spirit and the will to safeguard the ideals of freedom, justice, tolerance, and fair play. To be free, people must practice as well as give lip service to the Good Neighbor principle, which in essence means the recognition of the worth and dignity of each human being regardless of race, color, creed or social status.

Our librarians should be citizens who have broad perspective, a critical and constructive approach to life, standards of values by which men can live nobly, and a deep sense of responsibility for their fellows. They should be persons of integrity easily motivated to action in the cause of individual freedom, social justice, and international peace; who will use their leisure in ways creative and not corruptive; and who, as Barbara Jones puts it in her book on Bennington College, will go on learning throughout life, adapting themselves to change without losing conviction. We do not want citizens bounded on the north, south, east and west by themselves. We need more citizens who can make intelligent and wise judgments, and who will work effectively to good ends with others. Whether they be leaders or followers, we need citizens who are concerned about values in terms of integrity of character, motives, attitudes and behavior. The democratic way of life not only cherishes freedom, but entails obligations and even sacrifice for its preservation. Lastly, we need more citizens who have devotion for the public good and who regard the task of social amelioration as the surest road to greatness of achievement and personal satisfaction.

If these are the kinds of citizens we want our librarians to be, how do we get them? What should be their education?

At the college level I think the best results cannot be achieved by following a program that is not concerned with individual differences, intellectual and emotional; that is overloaded vocationally; that fosters narrow specialization; that is not rich in historic-cultural significance; that is not closely related to the contemporary scene; and, above all, that fails to utilize the concepts and findings of modern science.

The liberal arts should be the unifying and central element in higher education for citizenship and a professional career. There can be no substitute for teaching people, especially young people, how to live. During the last hundred years liberal education in this country has suffered from the inroads of overspecialization, vocationalism and professionalism. Our liberal arts colleges have become a collection of departments with little organic connection between them. As a consequence we have, as my colleague Dr. Ordway Tead puts it, intellectual fragmentation, befuddlement, philosophical anarchy, and spiritual blindness. Education for citizenship should rest not upon a series of specialized departmental courses, but upon carefully integrated divisional courses in science, the social sciences and the humanities.

In framing educational programs, those of us who believe that the primary concern of our institutions of higher learning should be the training for citizenship to the end that freedom may prevail, should give thought to one of the greatest problems

(Continued on page 112) 
that revised programs announced by several library schools indicate a trend toward greater emphasis on the theoretical aspect of librarianship and on books. Should this impression be correct, it may well be argued that there is no longer a valid reason for us to continue our experiment, even though it has been gratifying.

Courses, Academic Year 1948-49

\begin{tabular}{|c|c|c|c|}
\hline Course & \multicolumn{2}{|c|}{$\begin{array}{l}\text { No. of Sessions } \\
\text { (I } \frac{1}{2} \text { Hours Each) }\end{array}$} & Instructors' Position in Library \\
\hline $\begin{array}{l}\text { Printing (social eco- } \\
\text { nomic \& related as- } \\
\text { pects) } \\
\text { Documentation, Pt. } 2 \\
\text { Cataloging, } \mathrm{Pt} \text {. 2 } \\
\text { Service, Pt. 2 } \\
\text { Administration } \\
\text { Reading } \\
\text { Book Trade }\end{array}$ & $\begin{array}{l}13 \\
28 \\
31 \\
31 \\
20 \\
20 \\
13\end{array}$ & $\begin{array}{r}10 \\
12 \\
26 \\
15 \\
20 \\
10 \\
6\end{array}$ & $\begin{array}{l}\text { Asst. Librarian, Prep. Div. } \\
\text { Head, Circulation Dept. Asst. Libr., Prep. Div. } \\
\text { Head, Cataloging Dept. } \\
\text { Asst. Libr., Service Div. Head, Circulation Dept. } \\
\text { Director of Libraries, Asst. to the Director } \\
\text { Asst. Libr., Service Div. } \\
\text { Asst. Libr., Prep. Div. }\end{array}$ \\
\hline & Trainee & \multicolumn{2}{|c|}{ Graduate School Instruction } \\
\hline & $\begin{array}{l}\text { A } \\
\text { B } \\
\text { C } \\
\text { D }\end{array}$ & \multicolumn{2}{|c|}{$\begin{array}{l}\text { English Literature } \\
\text { Romance Languages } \\
\text { Oriental Studies } \\
\text { Russian Language and Literature }\end{array}$} \\
\hline
\end{tabular}

\section{Education for Future Librarians}

(Continued from page 102)

of our time-personal relationships in modern society. We no longer trust each other; honesty and frankness are at a premium; faith and confidence have tended to disappear. "I trust nobody" increasingly characterizes modern society; the sense of insecurity in human relationships is widespread. Fear haunts us; fear of being double-crossed; fear of being "taken in"; fear of "sticking our necks out"; fear of being victimized by a black marketeer. Fear and lack of faith are partially responsible for the hysteria, prejudice, religious fanaticism and diplomatic chicanery which characterizes the international scene today. Many of us will undoubtedly agree with the contention of Professor Howard Mum- ford Jones, of Harvard University, that perhaps the most tremendous task before higher education is to seek out means of restoring between human being and human being that calm and confident relationship which our western culture has lost, is losing and will continue to lose until psychologist and physician, sociologist and anthropologist, by combining their studies, can perhaps restore this faith to western man.

The person looking forward to a career as a librarian, who has this basic foundation in general education and on top of it builds the techniques and skills which he must have, is admirably equipped not only for his duties as a librarian but for his role as citizen as well. 